\title{
Managing Language Diversity in the Workplace: Between 'One Language Fits All' and 'Multilingual Model in Action'
}

\author{
Patchareerat Yanaprasart
}

\begin{abstract}
Department of Language and Information Sciences, Faculty of Arts, University of Lausanne, Switzerland School of French Language and Civilization, Faculty of Arts, University of Geneva, Switzerland
\end{abstract}

Copyright $\mathrm{C} 2016$ by authors, all rights reserved. Authors agree that this article remains permanently open access under the terms of the Creative Commons Attribution License 4.0 International License

\begin{abstract}
In order to meet global demands, multinational enterprises have developed practices of recruiting international staff. This, in turn, has led to a significant increase in cultural and linguistic diversity at all levels of the workforce and has thus created new challenges. One of them is to find how organizations can best manage and balance the need for divergence (complexity, diversity, differences) and convergence (cohesion, uniformity, standardization). In this context, English as a lingua franca is regarded by some as a condition for the universality of business knowledge and communication. This principle rests on the assumption that language is transparent, functioning as a neutral vehicle to express ideas and share discoveries. The premise that 'one language fits all' could impoverish innovation and creativity, leading to business monoculture and standardized patterns of thinking. A multilingual model in action affords a plurality of perspectives and ensures that objects and phenomena are seen through different prisms. Based on the content analysis of semi-structured interviews with agents at different levels in multinational, national and regional companies in Switzerland, this contribution will explore the challenges arising from language diversity in multilingual mixed team work. The impact of each linguistic diversity management model will be also identified. The main objective of this contribution is to procure detailed knowledge of different language regimes and the diverging relevance of linguistic diversity as a part of the organizational diversity management, by highlighting the complex interplay between contextual-organizational elements (organizational 'top-down' discourse), observed 'bottom-up' practices and actors' views regarding language ideologies. Understanding the complexity of language diversity management in the workplace can help companies to manage languages in an innovative way, to monitor their "diversity performance" and to identify clues and indicators to measure the success (or failure) of their diversity initiatives.
\end{abstract}

Keywords Diversity and Inclusion, Language Diversity Management Models, Language Use and Practice in the Workplace, Language Strategies, Multilingual Model in
Action, Multilanguage Capability, Multilingual Inclusiveness Cultural Workplace

\section{Introduction}

In this globalizing business context, people with different languages are required to work together, which leads to various forms of communication between colleagues who are more or less multilingual. Professional mobility across borders has made the workplace not only multicultural, but increasingly multilingual. Linguistic diversity emerges as one of the major challenges to the operations of multinational as well as national companies.

E. Mink [1] replied to the question "What are the challenges intercultural teams face?" that "A major challenge is the language problem - when you are unable to communicate in your native language". A multilingual Europe represents the challenge that the European Commission faces for the Europe of tomorrow. Linguistic diversity should be seen as an advantage rather than a series of problems for a knowledge-based society. Is this really the case? Which conditions must be met so that multilingualism results in an asset? And if "a multilingual workforce is a significant resource and can be a competitive advantage" (Akinci/Pohl [2], 26), diverse teams need to find a linguistic tool for cross-linguistic communication.

We will try to explore this question by analyzing the ways in which companies manage diversity at work, by identifying their arguments pointing to multilingualism as a resource (e.g. insisting on the value of diversity as an internal integration tool or on economic reasons to allow market adjustments) or, on the contrary, as a barrier ${ }^{1}$.

With this conceptual background, a set of problems arises, constituting the central theme of this article. This latter sets out to understand to what extent language practices are

1For the person in charge of diversity management of a Swiss national company, "language is always a first barrier" ( $<\mathrm{TCom} \mathrm{A}>$ ). 
managed in a multilingual team and which forms of language use, related to different linguistic ideologies, are perceived as the right strategy to overcome linguistic barriers. To what degree might it be possible for a "multilingual model in action" solution to be developed within "transnational space" (Appadurai [3]) practices, allowing language users to move "dynamic language boundaries" (Saulière [4])? In this framework, the main focus will be laid on possible tensions between discourse and practice. We will have to answer the questions of why linguistic diversity represents a major topic for business management, what are the ideologies of institutional and individual actors at different levels of hierarchy, how do social actors mobilize their linguistic resources in their professional practices and perceive the multilingual character of their work, and how companies prescribe language policy, by enforcing or reducing the dynamics of linguistic diversity at work.

Our reflections rely on a study mandated by the Swiss National Science Foundation (100015 147315), conducted from July 2013 to June 2015 in Switzerland. It sets out to understand how organizations can best manage and balance the need for divergence (complexity, diversity, differences) and convergence (cohesion, uniformity, standardization) by focusing on the way in which organizations manage diversity at work. The point is to uncover the language regimes and the diverging relevance of linguistic diversity as a part of the organizational diversity management.

The main research questions are the following: What is the impact of differences in language ideology and practices on the way that language diversity is handled in heterogeneous teams? How is language practices managed in a multilingual group? What could be a Linguistic Diversity Management Strategy? In what way does multilingualism contribute to the performance of organizations? In what way does language diversity impact team performance? Which forms of language use are perceived as overcoming linguistic barriers or deconstructing cultural boundaries at the workplace? Under what conditions can diversity and inclusion provide a strategic business advantage to companies? To what extent do businesses see Swiss multilingualism as an asset?

Whereas the overall objective of this two-year project relies on understanding the complexity of the meaning and management of diversity in the workplace, which can help companies to manage linguistic diversity in an innovative way, to monitor their "diversity performance" and to identify clues and indicators to measure the success (or failure) of their diversity initiatives, this article sets out to identify different models of the management of linguistic diversity in the Swiss multilingual business context through the analysis of local diversity management initiatives and practices as described by social actors. What measures and what strategies have been put in use to get the best benefit of linguistic diversity, source of diversity particularly salient in Switzerland?

This paper is a preliminary version of the findings of this project. For a complete version of the results, see
Yanaprasart, Patchareerat (Forthcoming). Chapter 2: The Challenge of the Management of Diversity and Sub-chapter 6.1. Multilingual websites. In Managing Plurilingual and Intercultural Practices in the Workplace. The Case of Multilingual Switzerland, ed. by Lüdi, Georges, Katharina Höchle Meier, and Patchareerat Yanaprasart. Amsterdam: John Benjamins.

\section{Methodology and Data}

As mentioned in the introduction, the focus of this article is, on the one hand, on the relationship between the political, linguistic, demographic context (cf. language policy, language philosophy, language planning ${ }^{2}$ ), forms of language management measures ${ }^{3} /$ initiatives, and language strategies/practices, and on the other hand on possible tensions between 'what is said' and 'what is done'. Our concentration relies on a complex relationship between these dimensions rather than on one aspect in particular. What interests us is to be able to identify the impact of companies' management measures on language use or on the ways such measures reflect language ideologies and behavior.

In this objective, we adopted a multi-methodological approach taking into account various observables while ensuring the coherency of the results and allowing comparisons and generalizations. At a "macro" level, we compared companies in different linguistic regions of Switzerland; at the "meso" level we analyzed different discourses within a single company to assess their polyphony; finally, at the "micro" level the focus is placed on the practices as described by the social actors.

A multi-methodological approach does not exclusively mean a combination of different autonomous or separated facets; the global result is viewed more as the total sum of its different unities. For example, data on language needs and language practices collected in interviews have been contextualized, analyzed and put in interrelations with discursive constructions. Our hypothesis is that if the ways in which a given political, economic, sociocultural or linguistic context is perceived by social actors may have an impact on their ideologies on language choice or language use, their perceptions about these latter may inversely influence policies and measures regarding linguistic diversity management. It is true that each of these dimensions can be analyzed with particular methods, but only a multi-methodological approach can better give an overview of the relations between them.

2De Groot $(2012,256)$ [114] calls "language planning", "a corporation's conscious effort to determine the status and function of multiple languages for particular forms of spoken and written communication."

3 Hagen $(2011,4)[115]$ defines "language measures", "the planned adoption of a range of techniques to facilitate effective communications with clients and suppliers abroad". He also speaks of "strategies" in the case of organizations. Language management measures, according to Minzberg/Waters [116], are often emergent rather than deliberate or intended. Piekkari et al. ([117], 204-205) distinguish between the formulation of strategies (setting goals and objectives and plotting a business path to their eventual achievement) and their implementation (the effectively strategic execution). 
The data collected comprise oral and written documents of many different types:

- Legal documents from the Federal Constitution of the Swiss Confederation, the Swiss Language Law, and several documents of the Federal Office of personnel of the Federal Department of Finances ${ }^{4}$.

- Official documents of organizations such as annual reports, press communications, internal magazines, brochures, guidelines, job ads.

- Corporate webpages, pictures, posters, advertisements.

- Oral documents such as semi-directed interviews.

This mixed-methods approach concerned not only the data collection, but also allowed a fine-grained analysis, through the analysis of discourse of the social actors about their practice, about their 'shared' or 'personal' opinions on what is written in official documents. Precisely, we conceived our research as a form of "involved linguistics" (Berthoud/Burger [16]), which implies a close interaction between researchers and practitioners. ${ }^{5}$ As a first step, we collected official documents indicating each company's philosophy, the concept of diversity and explicit management measures, as well as documents circulating in the companies and/or presented to the outside. In a second step, we proceeded to a semiotic analysis of the job description of the head of diversity, as well as of the diversity section on the corporate websites, be it monolingual or multilingual. Thirdly, we conducted semi-structured interviews ${ }^{6}$ with "people in charge of diversity"7, either "task-oriented" interviews with team members or team leaders or "policy-oriented" interviews with policy-makers, revealing their attitudes towards linguistic diversity. Our interlocutors came from the industrial sector and public institutions from both the German and the French-speaking regions of Switzerland and included scientists researching this issue, as well as consultants, coaches and trainers of diversity management. ${ }^{8}$ In the framework of this article, we will focus on the business sector.

\begin{tabular}{|c|c|c|}
\hline Company & Sector & Type \\
\hline Agro A & Agribusiness & Swiss-British international company based in Basel \\
\hline Bank A & Banking & Swiss international company based in Zurich \\
\hline Food A & Food/Beverage & Swiss international company based in Vevey \\
\hline Ins A & Insurance & Swiss international company headquartered in Zurich \\
\hline Ins B & Insurance & Swiss company headquartered in Winterthur \\
\hline Pharma A & Pharmaceutical & Swiss international company based in Basel \\
\hline Pharma B & Pharmaceutical & Swiss international company based in Basel \\
\hline Pharma C & Pharmaceutical & American international company based in Geneva \\
\hline Public Service A & Public service & Swiss national company headquartered in Bern \\
\hline Public Service B & Public service & Swiss national company headquartered in Bern \\
\hline TCom A & Telecommunications & Swiss national company headquartered in Bern \\
\hline Tab A & Tobacco industry & American international company based in Lausanne \\
\hline
\end{tabular}

Since the aim of this article is to identify language management models that internationals, nationals and regionals located or based in Switzerland use to get the best benefit from their corporate multilingual environment, the following conceptual framework part will focus on the literature review in the domain of language dimension in organizational diversity management.

4Instructions du Conseil federal concernant la promotion du plurilinguisme dans l'administrationfédérale, 2003. /

Office fédéral du personnel, Guide pour la promotion du plurilinguisme, Département fédéral des finances, Mai $2009 . /$

Promotion du plurilinguisme dans l'administration fédérale de 2008 à 2011, rapport d'évaluation au Conseil fédéral, Office fédéral du personnel, Département fédéral des finances, 2010

5 More precisely, the interventions of the actors in the field are situated at three levels: Common project development, taking into account their needs; semi-directive interviews, giving them a voice; and returning to their grounds with the results (knowledge transfer activities).

6The interviews were conducted in English, and the citations in this chapter are in their original versions.

7 The appellations of job positions vary from one organization to another. In the public sector, we can numerate Head of diversity, Delegate to equality of chances, Delegate to integration, Delegate to plurilingualism, Responsible for diversity management, Chief of equality of chance and global questions on men and women. In the industrial sector we find :Director of Trial Conduct \& CDO, Data Services, Corporate HR, Talent \& Organization Development, Head of Employees Relations, Leiterin Kommunikation, Miglied der Konzemleitung, Head of Diversity, Head of Diversity and Inclusion, Head of Diversity \& Family care, Talent \& Learning Manager, Chief of Diversity and Human resources, Responsible for diversity management, Vice-president of Diversity and Inclusion, HR and Diversity Manager, HR Expert, Diversity \& Inclusion, Senior Manager Global Diversity \& Inclusion, Global Head of Diversity, Group Head of Diversity \& Inclusion, Group Head Talent Management, Talent Acquisition, Diversity \& Inclusion, Diversity Project Manager, Global Head of Diversity and Gender Balance. To facilitate reading, the term Head of Diversity and Inclusion (D\&I) will be used when mentioning the people in charge. 8 The main questions addressed in the interviews were to identify how these specialists define diversity and diversity management, what their philosophy on managing diversity is, how they help companies to manage their diverse workforce, what their areas of specification are and how they measure the impact of their recommendation and training. 


\section{Linguistic Diversity in Diversity Management: The Challenge of a Multilingual Reality}

Zhu ([6], 23) advances that "the workplace is not only a physical space where people work, but also a social space where people meet, interact and build relationships". Regarded as a fact of life (Louhiala-Salminen [7]), the way language is shaped and managed is not, however, a neutral factor in the process of communication, interpersonal exchanges, knowledge sharing and transfer (cf. Welch/Welch [8]). The choice of language and the power of language use in business contexts are, therefore, not negligible. A number of studies on the role of language in the processes of inclusion/exclusion and in the creation of power relations (Angouri [9]; Vaara et al. [10], Feely/Harzing [11]; Lüdi/Höchle/Yanaprasart [12]) can be found.

The social tensions generated by the choice of language or the way it is used have also been documented in a growing body of research (Steyeart/Ostendorp/Gaibrois [13]; Janssens/Steyeart [14]). As a matter of fact, language use can hinder or enhance cooperation among co-workers (Lüdi/Höchle/Yanaprasart [15]), and can affect the performance of the company as a whole (Chen/Geluykens [16]; Welch/Welch [17]). Language practices are fundamental for the construction of cultural and linguistic boundaries in an organization, in the sense that it is through language use that cultural and linguistic group memberships are identified, problematized and negotiated and thus barriers between organizational members are established, modified, reinforced or deconstructed.

The preceding discussions afford some insights into the importance of bringing language to the forefront, to explore and explain how and why language matters in dealing with the multilingual reality of global business expansion. However, while the positive impact of linguistic diversity in the workplace has been shown in a number of studies (Marsh/Hill [18]; Grin/Sfreddo [19]; Berthoud et al.[20]), the language factor seems to be rarely conceptualized as a critical element of the performance of heterogeneous teams (Marchan et al. [21]; Adler/Gunderson [22]; ManchenSpoerri/Hohenstein [23]). Piekkari et al. [24] recognize that language has been too easily ignored, a forgotten factor, because it has long been subsumed under the culture umbrella. Somehow, "this is somewhat understandable, as language effects are not always obvious. They are often opaque, not readily seen", argue the authors $([25], 11)$, in the sense that "one might argue that language is unimportant until that happens" ([26], 14).When dealing with the planning of internal as well as external communication in companies, top management often views organizational language as a problem that can be solved through systematic translation ${ }^{9}$. Another way of removing the language problem is to hire employees with the requisite

9 "If you think about all the translations we have to do, it's a lot of cost." (Head of D\&I, <Bank A >). foreign language skills or to provide language training.

As a matter of fact, language covers various instrumental functions in business contexts. When it comes to looking into the effectiveness of an organization's language policy, obviously, this is a factor to be reckoned with. As Van den Bergh/Lehmann [27] puts it, the mixed teams' members cannot best exploit their diverse skills without possessing common means of communication. Organizations need some effective "language management strategies" (Hagen [28]; Kameyama/Meyer [29]) if they want to take full advantage of their strengths.

It is from the instrumental-oriented perspective that the issue of language in management research is likely to study various practices of language use, for example oriented towards problem-solving (Gaibrois [30]). Some scholars (Harzing et al. [31]; Blazejewski [32]; Fredriksson et al. [33]; Harzing/Feely [34]) approach linguistic diversity through the notion of the 'language barrier', which has to be overcome. For Maclean ([35], in Planken [36], 12), the question of language "has been considered above all as a 'pragmatic' problem, which can be solved easily by hiring translators or interpreters, or by choosing a communal corporate language to facilitate internal communication in multilingual environments". This belief is based on the concept of language transparency, in a mechanical view of communication (Janssens et al. [37]) or purely instrumental (Lecomte [38]) (see Berthoud et al. [39] for counter-arguments), and may explain the reason why language was identified for a number of years as the 'forgotten factor' (Marchanet al. [40]), 'the most neglected field in management' (Reeves/Wright [41]), the 'orphan management' of international management (Verrept [42]) or of international business research (Feely/Harzing [43]). As Studer/Hohenstein [44], 9; ManchenSpoerri/Hohenstein [45], 7 conclude, "despite the widespread call for greater attention to language as a relevant factor of business performance", and firms "are often reluctant to include language within their diversity management portfolio". Finally, in Planken's view ([46], 12), "language is likely to remain low on the agenda", as long as no way is found "to objectively measure the impact of language or language choice on individual or organizational effectiveness".

When it comes to overcoming the so-called "language barrier", a tension due to the diversity of perceptions regarding the meaning of "language use" has often been identified. For some, it is about speaking "standard languages" from the normative perspective, based on the notion of relatively fixed and stable language borders. For others, when languages come in contact, they are so deeply intertwined with each other that it is difficult to determine any boundaries among the different languages involved. Among language users in linguistic heterogeneous teams, some advance that what prevails in multilingual business settings is not 'perfect' language knowledge, but a 'pragmatic' way of using language when attempting to find appropriate solutions to particular problems. From this point of view, multiple-language-use choices constitute an alternative to 'overcome' language barriers and 
'deconstruct' cultural boundaries. Others pretend that using only one common corporate language is the best way to 'bridge' the gaps, 'cross' linguistic borders and 'give' equal access to all participants in interactions. In this sense, standardization takes over diversity.

On this question, Feely/Harzing [47] mentioned the high costs of the language barrier. A common language (Kogut/Zander [48]) for the internal communication of multinationals is seen as a panacea for the problem of language differences by many theoreticians to reduce "the costs and 'noise' caused by multilingualism" (Luo/Shenkar [49]). A language where leaders see the world's business challenges as opportunities, think with an international mindset, act with fresh global-centric leadership behavior and mobilize world-class companies is recommended by Hoecklin [50]. Large [51] appeals for a universal language that would be unambiguous and have the facility to describe things as they truly are. We can find other propositions like $a$ special (code) (Peters/Waterman [52]), an ideal language (Steiner [53]), or a shared spoken general language (Hedlund [54]). The term grammar and lexicon of management is used by Collins [55], whereas Senge [56] calls for a new language of relationships. In terms of Argote el al. [57], it is all about a 'short-hand', 'home-made' language. Phene et al. [58] recognize a shared language as a component of corporate identity enabling a multinational to transmit and share knowledge. Regarding Holden [59], the language of management is the informal language of know-how, the carrier of best practices. This kind of language allows people to be able to make sense to and of each other, as Hedlund [60] argues. In Peters/Waterman's view[61], an excellent company needs a code that is a consequence of interactions throughout the company.

In the context of globalized business settings, the choice of one official corporate language, although not "fully effective" (Harzinget al. [62], 285), is more and more opted for by companies as one possible solution. In an international business context, English as a global lingua franca is chosen the most (Abdullah/Chaduhary, [63]). Whereas Vandermeeren [64] identified three major language regimes: (a) the company imposes its own language (the language of its home country or its corporate language), (b) it accommodates the others' language, and (c) the interlocutors use a "neutral" language (standardization), the question of Barner-Rasmussen/Aarnio [65] is if a language system can be designed by top management.

Some of the dysfunctional effects of installing English as the corporate language have been pointed out by Heikkilä/Smale [66]. The study of Lüdi et al. ([67], [68]) requires an interpretative approach to investigate how people experience and make sense of working in a linguistically diverse team. Its aim is to identify tensions between the official language policy and the effective use of English as a business lingua franca (cf. Maclean [69]). It has been shown that if English is the language of business, other languages are also used in multilingual workplaces (Angouri/Miglbauer [70]; Berthoud et al. [71]; Lüdi [72]). Indeed, some studies emphasize that if Business English lingua franca is a 'must' and a plurilingual repertoire is activated and sometimes even appreciated strategically (Ehrenreich [73]; Pullin Stark [74]), others show how plurilingual resources come in to play within 'THE language of business' in the professional workplace (Lüdi et al. [75]; Lüdi [76]; Cogo [77]; Hülmbauer/Seidlhofer [78]). Other languages than English are important for work matters: not only for relationship building (Charles [79]; Chew [80]; Erling/Walton[81]; Evans [82]; Zhu [83]), but may also serve as multilingual franche (Cogo/Yanaprasart [84]).

It is important not only to be aware of any potential tension due to the diversity of perceptions regarding the best language management model, but also to analyze language ideologies that are caught between a tendency towards internationalization and the perception of individual multilingualism and institutional multilingualism considered as an opportunity and an asset. This is worthy of development in the following section. Its aim is to better understand how social actors mobilize their linguistic resources in their professional practice; how they conceive, actively or passively shape the multilingual and multicultural character of their work; and how institutions regulate, prescribe, enforce or reduce the multilingual dimensions of different language dynamics.

\section{Findings: Models of Language Management Philosophies}

\subsection{Language Issues in Today's Organizations}

For Schnurr [85], social and economic changes impact on professional communication in a variety of ways, and this includes the use of English and other languages as lingue franche in intercultural encounters. Indeed, the following assumption is quite recurrent in our data: "speaking many languages is obviously advantageous. This is something good for your career in the future" $(<$ Public Service A $>$ ). According to the opinion below, being multilingual results in competitive differentiation.

But I want to say today speaking only English, it is not sufficient in the professional world. But ... when we look around ourselves, speaking only English, French and Romanian ... I'm lucky I can add Russian and suddenly I stand a little bit out from the crowd. (PLC) 
In terms of strategies, Dyer [86]estimated that a high percentage of them are an outcome of strategic adaptation - flexibility in order to cope with any change, opportunity or crisis. For Piekkari et al. [87], the approach to language is often more a matter of an ad hoc response to the reality of language diversity rather than being deliberate or planned: "the need of a language strategy is a consequence of the firm's overall strategy". But language strategy "tends to be well behind in terms of consideration compared to other corporate strategy components" ([88], 206). However, without a doubt, language as a resource for leveraging the firm's performance does not belong to the firm itself, but is largely in the hands of its individual employees. They make choices about whether, when, how and with whom they can take full advantage of any language skills for the company's interests, or on the contrary, employ them in a way that can become disastrous for the firm. ${ }^{10}$

In line with what Maclean says: "companies deal with language issues every day" ([89],137),"language management and promoting multilingualism in the company is absolutely important for us, very important and we don't do enough about it and don't do it explicitly. This is kind of implicit, how we manage this" as Head of D\&I at $<$ Bank A $>$ highlights. However, when it comes to the question of the role of language in diversity management, some interviewees were surprised:

What I found very interesting is that you brought a view to diversity which I haven't really considered in that sense. I am thinking about culture, but [not] about language and how you use it also to increase diversity and inclusion, that's very interesting aspect to think about. How language influences some practices? How can you increase inclusiveness by language? (Vice-president, $<\mathrm{Tab} \mathrm{A}>$ ).

The presentation of several models of language management philosophies in the following sections allows us to see how our different study fields are dealing with the challenge of linguistic diversity in the workplace and how they justify their choices. First and foremost, it is highly relevant to note that the use of one common language as a 'corporate language' is not always officially recognized by the company's language policy (explicitly written document). Based on the perceptions of our interviewees, a distinction between 'corporate language' and 'official language' has to be made. While the first term is recognized as the language that the company uses to communicate internally as well as externally, the second term refers to the company's formal language of management and business. Either one or the other may be a local, a regional, a national or an international language. When being used as the language of daily correspondence and conversation, that language may or may not be an official one.

\begin{tabular}{|c|c|c|c|c|}
\hline Internationalization & & & & \multirow{2}{*}{$\begin{array}{l}\text { Multilingualism } \\
\begin{array}{|c}\text { "Institutional } \\
\text { trilingualism" (4.6) } \\
\text { (3 official corporate } \\
\text { languages + ENG) }\end{array}\end{array}$} \\
\hline $\begin{array}{l}\text { Monolingual language } \\
\text { philosophy" (4.2.) } \\
\text { Global English policy }\end{array}$ & \multirow{3}{*}{$\begin{array}{l}\text { "Monolingual institutional } \\
\text { multilingualism"(4.3.) } \\
\text { (1 official language }+4 \\
\text { languages in use) }\end{array}$} & \multirow{3}{*}{$\begin{array}{c}\text { "Bilingual Institutional } \\
\text { Language } \\
\text { Philosophy"(4.4) } \\
\text { (2 administrative } \\
\text { languages) }\end{array}$} & \multirow{3}{*}{$\begin{array}{c}\text { "International } \\
\text { Multilingualism"(4.5) } \\
\\
\text { (AM ENG corporate } \\
\text { language + } 3 \text { national } \\
\text { languages) }\end{array}$} & \\
\hline (1 corporate language) & & & & \\
\hline & & & & \\
\hline
\end{tabular}

10It is to be noted that none of our interviewees is monolingual. At a minimum they can speak two languages; the majority of them have the ability to undertake professional tasks for company purposes in five languages. 


\subsection{Global Monolingual Solution}

For the purposes of internal communication, many interviewees have highlighted the necessity to choose a single working language for resolving internal communication problems, the solution known as OLON ("One Language Only", e.g., Yanaprasart [90]) or CCL ("a Common Corporate Language", cf. Piekkari et al. [91]).Given its place as a global business lingua franca (Abdullah/Chaduhary [92]), English is often the first port of call when it comes to the choice of a single language.

\begin{tabular}{|c|c|c|c|}
\hline Bank A & Pharma A & Agro A & $\begin{array}{c}\text { Ins A } \\
\text { Food A international }\end{array}$ \\
\hline $\begin{array}{l}\text { English is the official } \\
\text { management language }[\ldots] \text { of the } \\
\text { company or the language of } \\
\text { Banking is English. English is the } \\
\text { official language of }<\text { Bank } A> \\
(<\text { Head of D\&I, }<\text { Bank A }>\text { ). }\end{array}$ & $\begin{array}{l}\text { English is the company language; } \\
\text { fluent English is therefore } \\
\text { required. (Job ad on line) } \\
\text { Predominantly, the language used } \\
\text { here is English. You need a } \\
\text { common ground and English is } \\
\text { clearly the language that is spoken } \\
\text { commonly in business D\&I } \\
\text { Project Manager, }<\text { Pharma A }>\text { ) }\end{array}$ & $\begin{array}{l}\text { Generally speaking }<\text { Agro } \mathrm{A}>\text { is } \\
\text { predominantly English-oriented, } \\
\text { like most multinationals. (Head of } \\
\text { Personnel and Human Resources }\end{array}$ & $\begin{array}{l}\text { This is a company whose } \\
\text { corporate language is English. } \\
\text { Our corporate language is English }\end{array}$ \\
\hline
\end{tabular}

The statement of Müller-Jensch ([93], 55) that job markets are more open because it is not obligatory to speak the local language in order to find a job is also illustrated in the interviews with the Head of D\&I at $<$ Pharma B $>$. English as an international language allows the company to recruit a wider talent pool. And since English is one of the most widely learnt languages, it gives a common way to communicate to worldwide talents, a role that local languages cannot assume. Indeed, as $<$ Ins $A>$ insists, "you have to be good in English. The first question we ask to the person who wants to work here is, do you speak English?" (Head of D\&I).

The case of $<$ Ins A $>$, an insurance company headquartered in Zurich, can clearly illustrate the focus on English in MNCs. Its Head of D\&I describes the firm as 'quite global, very international and very diverse in the sense of nationalities'. This internationalization attracts people to work at the company ${ }^{11}$. Even if this 'so international' aspect brings languages along ("and that brings many languages along as well"), it is English that the company chooses as its corporate language. Language choice and language management measures neither are neither the company's focus nor come out in conversation.

In this firm, everyone is expected to speak English. Officially, internal and external corporate communication is generally in English, published documentation is mainly in English even if some documents may be in German locally. This person in charge of diversity management has even interiorized the 'English only' philosophy in her language behavior. Despite her knowledge in several languages, she intentionally represses the other languages of her plurilingual repertoire based on the representation that the official language should be her only working language because she is "most eloquent" in it ${ }^{12}$.

11I think the fact that it's so international; it's one of the big attraction points for many people to come to work at $<$ Ins A $>$.

12I speak Welsh, Italian, German and I understand French and Spanish. This is not really useful for my work. The corporate language is English; I need to be very eloquent when I speak. And on this topic, my most eloquent language is English. My Italian is very good but I don't work with Italian on this topic. My German is good but I don't sound professional in German like
Nevertheless, as we only had access to the practices in companies through what our interviewees told us, it is very probable that the implementation of the 'English only' policy is not entire and leaves much more space to plurilingual communication in daily life than it is said here.

\subsection{Monolingual Institutional Multilingualism Strategy}

Language diversity remains an issue in international business encounters even while English is largely used as a 'contact language' (Seidlhofer [94], 339). The global monolingual solution has not rendered the business world monolingual, because the reality of today's business context remains multilingual. This starts with the form of the English ${ }^{13}$ employed.

Many of our participants are aware that it is not Standard British or Standard American English that makes up for the richness and 'international identity', but English spoken with a "multinational dressing":

So it is English with Spanish dressing, English with French dressing, spoken with the Japanese, Chinese way, because we're really an international company, it makes also the richness of this company (...). So there is a high tolerance vis-à-vis how to speak English, it is not literary English (MC, French employee, $<$ Pharma $\mathrm{B}>$ ).

One of the results of our previous research is that 'English as lingua franca' is in fact a form of plurilanguaging (Hülmbauer/Seidlhofer [95]; Markaki et al. [96]; Lüdi et al. [97]). As illustrated by the following "Application Line" dialogue between N., a French-speaking Canadian from Quebec, and her colleague P., working in Hong Kong, She speaks English, Cantonese and Thai fluently:

I do in English. So I choose not to speak these languages in the workplace. [...] Even if I'm going to work in Italy or Germany, I maintain English as the working language.

13 For Canagarajah [118], there is not one English lingua franca, but Englishes lingue franche or "Plurilingual English". 
N: Hello P. Yes we can do this tomorrow morning because un the afternoon we Will go to Macau! Call us

P: I can't do tmrw morning My sister's last day here When $r$ you back?

$\mathrm{N}$ : Thuesday afternoon ans we are Free wenesday too. Let me know when! Good night

P: Tuesday or Thursday? You meant you are back on

Tuesday $\mathrm{n}$ free on Wednesday moring? I meant back from Macao.

$\mathrm{N}$ : We are free on thusday afternoon and wenesday all day. We come back to Macau thusday morning.

P: Tuesday mardi (google translate image)

$\mathrm{N}$ : Hhahaha yes thuesday!

P: Your spelling is Thusday I don't know you meant Tuesday Or Thursday

$\mathrm{N}$ : We come back thuesday morning m'y mistake!

P: Ok Mardi afternoon I will pick you up at $4 \mathrm{pm}$

After many repeated questions to N. about the spelling, it still remained unclear for P. if 'Thuesday' or 'Thusday' means Tuesday or Thursday. The story ended well when P., in the search for communicational clarity, decided to solve the problem of misunderstanding by opting for French-English coding: mixing 'mardi afternoon'. By giving the translation of Tuesday in N.'s first language and because this latter mentioned 'Wenesday', the day she would be free and also 'Thusday afternoon', P. concluded that it should be Tuesday, then 'mardi' in French.

Without the relevant fluency in a common language, a collaborator may be unable to control the flow of information: "it's very difficult to say great ideas in bad words ${ }^{14}$ " deplores the Head of D\&I, of $<$ Pharma B $>$; " if you don't speak the language or are kind of reluctant because you are not good enough in this language; good ideas might not be heard", seems to agree the Head of D\&I from $<$ Bank A $>$. As she continues, "I think if you don't speak English, it will be difficult to progress in your career".

Unsatisfactory competences in the working language(s) may constitute trouble not only for companies in their management, but also for employees' careers. Consequently, companies have started to look for possibilities of using more than one language for communication. The chosen solution mostly responds to the 'OLAT' principle ("One Language at $A$ Time"), meaning that even if more than one official language is allowed, those varieties are not supposed to be mixed.

In the example of $<$ Bank $A>$, an international Swiss Bank headquartered in Zurich, choosing to rely on a variety of languages, including the local ones, is practical for many reasons. First of all, it is not easy to find local candidates; but the company benefits from Switzerland's ability to attract highly educated people from abroad. Consequently, its

14I remember somebody said it's very difficult to say great ideas in bad words. I have this wonderful idea in my head but the way it comes out in the foreign language sounds nothing like how eloquently I could say in my native language. It's a little bit broken, I have an accent, I have to think. (Head of D\&I, $<$ Pharma B $>$ ). employees represent 150 nationalities. Despite stating that "the language of banking is English, to serve people all around the world" and it becomes logical that "English is the official language of $<$ Bank A $>$ ", the Regional Head of D\&I for Switzerland recognizes that "English is not enough in Switzerland", which has become a big challenge for $<$ Bank A $>$, especially for her American colleagues. Her experiences have highlighted the importance of Swiss multilingualism as a big advantage for the companies based in this country; the main clients are Swiss, it is necessary to have employees speaking the language of the clients. Correspondingly, the corporate websites, global (.com) as well as local (.ch), of $<$ Bank $\mathrm{A}>$ are proposed in four languages in the following order: EN, DE, FR, IT (English, German, French and Italian).

Without a clearly written document on language policy but based on an email from the CEO "saying that English in the Bank would be American English, and not British English", explains the person responsible for internal English training, employees sometimes feel unsure about what the corporate language is. Still, this lack of clarity in language policy or rather a certain freedom in language choice is perceived as positive to the extent that the personality and originality of professionals can be valorized:

Here at $<$ Bank $\mathrm{A}>$, it's not really clear what the corporate language is. Because we have a lot of freedom to do things in German, or Italian or Japanese or Portuguese or whatever, and I also like this. It makes it NOT EASY but I think it's good also for the people because it's part of their personality, part of their originality. (Regional Head of D\&I).

Some other employees perceive the way their company manages language diversity as confusing and problematic, like the obligation "to do multilingual reports" or the recommendation to "speak at least a few words in French" when going to Geneva or Lausanne. "It's nice to speak some words in Italian" "if you go to Ticino". As this interlocutor suggests, "sometimes it's more important that people speak Swiss German than English or speak French or speak Portuguese or Chinese or Japanese".

Following the argument of the individual responsible for internal English training, "this multilingual communication mode seems to allow a culture of rich discussion". Three national languages serve as pragmatic lingue franche: "If one language does not work quite well, let's use another one". Her attitude is, "If I am with German speakers and I am the only English speaker, I feel bad if I speak English". In the conclusion of the Regional Head of D\&I, "two languages dominate in our daily work, English and German", because "using only one language, this latter can turn out to be the wrong one. Speaking both languages alternatively seems to be a good solution".

Lastly, to deal with language issues, translation services are proposed to "ensure today that all work instructions to this part of our employees is available in German". Some documentation is printed in a multilingual mode. Participants 
in the company's events are invited to contribute in the language(s) of their choice: "no one is forced to talk in English". Even if it is "just natural" for a younger generation to speak this international language, the company has "to be careful not to forget about the people not speaking English".

\subsection{Bilingual Institutional Language Philosophy}

The geographical setting of $<$ Pharma $\mathrm{B}>$, a pharmaceutical multinational company located in Basel, where it has its headquarters and a local affiliate, causes some tensions concerning the question of a common language: are we Swiss or is the company international?

There are some people who feel, yes but we are based in Basel, Swiss, we are family owned company so that feeling of German is our native language, German is our company language (Head of $\mathrm{D} \& \mathrm{I}<$ Pharma $\mathrm{B}>$ ).

The tension between the ("WE") locals and "the (THEY)" internationals represents a big challenge for the management "to have the majority - minority in balance", said the Head of D\&I.

... because we have a vast majority preferring German and a minority with a $20 \%$ preferring English, there is an imbalance because the majority group feel, but we are the majority why should WE do the effort and speak in English, why don't THEY learn German? (Head of D\&I, $<$ Pharma B $>$ ).

What can be the best company's language policy? There are some who know German but not English, others speak Swiss German and have never learnt High German. However, English means a much wider talent pool for recruiting new collaborators, and this language is needed for promotion: "the higher up you go in the hierarchy, the more English will become a requirement", explains the same interlocutor. For the local affiliate of $<$ Pharma $\mathrm{B}>$, as another person in charge of diversity management clarifies, "there is no formal requirement that everybody at the site has to know English because it's based on the job need. So whatever the job requires becomes the requirement for that job".

For these historical and structural reasons, the company decided that German is to be administratively used alongside of English, internally as well as externally. The parallel language use is an administration management tool that helps "global and local" operations to proceed efficiently. German, the local language of the Basel headquarters, is used with "[the English] language internationally recognized by all". This "two languages" solution strategy not only bridges the linguistic gap in internal communication, but also "create an inclusive environment", in the view of the Communication Group's Head at $<$ Pharma B $>$. As Harzing/Pudelkosuggest [98], multinationals that have 'linguistic duality' may have a competitive advantage over those that are monolingual.

In the eyes of the Head of D\&I, speaking their mother tongue makes people more comfortable, especially at the emotional level ${ }^{15}$.Indeed, if (language) diversity is a fact which needs efficient management, a real challenge for the company is to create an environment where people's diversity can actually thrive, the final aims being "to be successful together" $(<$ Pharma B $>)$ and " to feel good inside the company" $(<\mathrm{TCom} \mathrm{A}>$ ). Making employees feel comfortable is not just a duty of the company, but also of the team leader. Consequently, this Head of D\&I wants her team to be linguistically mixed, reflecting the corporate linguistic diversity. Both German and English are necessary for D\&I activities.

I need a team where there is a balance of knowledge, skills and competencies. So if I did not have the colleague who is German speaker, I would have had to create a profile where German is a must. Because I need this knowledge in the team for trainings, for communications for those employees who don't know English and they are still a part of our site. (...) We are also expected to be able to deliver trainings in English or in German, that we are able to communicate with the employees in English or in German. So from that perspective, my team needs to reflect also that diversity. I have team members who are comfortable with German. I need team members who are comfortable with English and I need ideally team members who are comfortable with both (Head of D\&I, <Pharma B >).

In her professional contacts, German speakers prevail. This also means that she herself, despite being more fluent in English, often uses German, which is her third foreign language after English and French (Arabic is her mother tongue). At the end of this bilingual working process, the final text is translated from German to English:

The vast majority of our communications managers are German speakers so when they write text, they write in their native language which is German. So I usually get the first draft in German that I need to read and review. I give my comments in English (laughs) and then they work on it and I get another draft. And then that final German text gets translated into English. (Head of D\&I, <Pharma B >).

In addition to this professional-based reason choice, the promotion of German is an important tool for integrating foreigners into the local society. Clearly, languages also cover phatic functions in the workplace - they can be used for greetings, small talk, index solidarity, close relationships and cultural identity. Our interlocutor views that English is assigned to the business function and local languages to the phatic functions.

15There are colleagues who are not very comfortable with English, who would prefer during their pauses, during their breaks they speak in German. When they speak their native language, it's just they are more comfortable. It's just easier, you can just express easier yourself, especially when you are emotional, how you feel (Head of D\&I, $<$ Pharma B $>$ ). 
I said to my team members that German is important for the integration. You connect to people differently, even on the social level, when you try to speak the language even it's little, oh you know Guten Morgen, wie geht es dir? Just little things like this. I do also with my French colleagues because I know French even though their English is perfect [...] it gives them the opportunities to speak their native language (Head of D\&I, $<$ Pharma B $>$ ).

Thanks to her good competences in the two working languages, this head affirms that language-switching and mixing are not an exception in her daily working interactions.

With a colleague from Germany, on Thursday, I try to speak German (laughs). If I can't, I switch to English. If I have a meeting and I am asking how she is or she wants to share with me something that is boring her, she feels free to switch to German if that is more comfortable for her because I would understand the majority of what she says. I was just not able to respond as well as she would be in German. So we mix, actually it's a mix. (...) Also yesterday I had a meeting with two colleagues, they are both German speakers. They asked, so what language do we speak now? And I said, well you can speak in German if I can respond in English and they said that's fine so we started this way (Head of D\&I, $<$ Pharma B $>$ ).

\subsection{Institutional Multilingualism Model}

$<\mathrm{Tab} \mathrm{A}>$ is an American international company based in Lausanne. According to the Vice-president of Diversity Management and managing director (who speaks French, German, English, Spanish [mother tongue] and understands Italian), her team is also a highly multilingual one where everybody speaks at least two languages. As noted by Piekkari et al. ([99], 14), "staying within one's language comfort zone helps reduce psychic distance". For Babcock/Du-Babcock ([100], 376), "it is not only the languages that communicators speak, but also the language fluency of such communicators that matters". As a leader, making her interlocutor feel comfortable is her ultimate aim. The Vice-president always accommodates her partner's language choice: "When we meet altogether, we speak English. In individual exchanges, with an Argentinian lady, I speak Spanish. With Christ, I speak German". When it comes to the translation issue, this technique is not always recognized as the most efficient way of dealing with business conversation. In oral communication, she does not hesitate to step out of her linguistic "comfort zone".

In general I try to speak the language of the majority, High German, Swiss German or French even if it's not really my comfort language. I try to make people sitting on the other side comfortable even though sometimes I was getting out of my comfort zone in doing that. (...) Sometimes I'm mixing (Vice-president, $<\mathrm{Tab} \mathrm{A}>$ ).

However, the choice depends a lot on the nature of communication, mostly in English (in writing) or naturally mixed (in face-to-face contact). The setting is also an important factor: in the operation center, an international unit located in Lausanne, English is used more due to the global nature of the function. In addition, a specific language or the French local language is also required, this depending on the position. Principally, job advertisements are issued in two languages, including French and Italian in the respective linguistic regions.

If at first glance, the situation of $\langle\mathrm{Tab} A>$ is not so different from the one in $<$ Pharma $\mathrm{B}>$, in contrast to the Swiss multinational company, the American international company proudly announces that the internal and external communication is in many languages. Externally, "in the Swiss market, everything is basically translated into three national languages (GE, FR, IT)", as made clear by the Vice-president. Both the Vice-president and the Head of $D \& I$ at $<$ Tab A $>$ agree on "a mix of everything" in the Swiss market: "it can be in German, it can be in French, it can be in Italian", clears up one of them. Like in other cases, language proficiency requirements depend on the position and the function: English is required in line management, whereas at a lower level, "you need to speak the language of your local team", concludes the Vice-president. This pragmatic language functionality is also underlined in what the Head of D\&I of $<$ Pharma B $>$ says.

\subsection{Institutional Trilingualism Choice}

Three Swiss national companies headquartered in Bern $<$ Public Service A $>,<$ Public Service B $>$ and $<$ TCom A $>$ are convinced of the obligation of a public company to represent the identity of its society: Swiss multilingualism "Our society is multilingual, so we want to represent inside what's happening outside. As we are a public company" $(<$ Public Service A $>$ ).The company promotes multilingual strategy everywhere: "on the intranet, internet, all of our brochures, documentation, in three languages". "Everything is translated, we also do it in English", confirms the Head of Diversity of $<$ Public Service A $>$. The company insists on initiatives to promote multilingualism, through language courses and internships; it is mandatory, in addition, for trainees to work for one year in an office in another linguistic community.

Regarding customer orientation, the same logic is found at $<$ Public Service $B>$ : the company has to represent its customers coming "from all over Switzerland" in its "personal mix", says the person in charge of diversity. Managing language issues well means publishing documentation in three national languages, or recruiting plurilingual employees: "we all have to speak more than one language, also here [Bern]. What I've heard from marketing, more or less, all jobs must have at least two languages; at least, German and French, German or Italian or whatever, 
this also in operation. In fact, more or less everywhere; people appreciate if you can talk in their language", explains the Head of Diversity.

Like at $<$ Public service A $>$, where the common rule in oral communication is everyone's right to speak his language ${ }^{16}$, with the principle of lingua receptiva (see Kolde [101]; Werlen [102]; Lüdi [103]; ten Thije/Zeevaert [104]), language mixing in the workplace is a common means of internal communication among representatives of the three linguistic communities, as claimed by $<$ Public Service B $>$ 's Head of D\&I. At <TCom A>, "individuality" means being able to speak in one's own mother tongue, highlighting the importance of collaborative practices: translations among peers in case of need ${ }^{17}$.

Despite this official rule, the fine-grained analysis of effective language use in these national companies (Lüdiet al. [105]) has shown that the communicative strategy chosen by these plurilingual individuals is much more complex than just choosing one common working language, or respecting "the rule that everyone shall be able to speak his or her language", as explained one more time by Marlène R. from $<$ Public Service A $>$. Her colleague, the person in charge of intercultural communication observed the same phenomenon on language use in meetings:

What often happens, in my experiences of meetings in other business units, I notice that French speakers or certainly Italian speakers, they speak German because they're afraid they won't be understood if they speak French. And they want their message to get (across).

Sometimes everybody decides 'Okay, we're going to speak English today'. Sometimes it's French and then other times it's a mix. (...) No one sticks rigidly to his own language. And then you suddenly find the French speaker doing part of the meeting in German.

Social actors do not stick to their mother tongue, but exploit their respective linguistic repertoires in the form of language-mixing to achieve communicative goals (Lüdi [106]). As Marlène R. re-emphasizes: "in everyday life you always find examples of people from the Romandie telling me I prefer to write my mail in German to be sure to get an answer. Such examples exist". Their multilingual repertoires allow the speakers to adjust their speech, adapt their language choice and accommodate others' communicative behavior and competences for a better co-constructive result.

\section{Discussion}

This paper has drawn attention to the various models of

16There is a rule; everyone has the right to speak his language. So I can talk in German, and French-speaking colleague talks in French. There is like expectation that I understand French but I don't have to talk, and it works. (Head of Diversity, $<$ Public service A $>$ ).

17 We have decided that a French person can speak French, and if the German person doesn't understand then she or he needs to ask his/her neighbor and his/her business meeting partner if she or he can translate for him/her because everybody needs to be in his own individuality. That's very important.(Head of Diversity, $<$ TCom A>). language management and practices in Swiss multinationals and national companies. Through the variety of language diversity management philosophies identified, the development of language policy seems to be influenced by corporate image strategy ("we are an international company"; "our company is multilingual"), rather than being first and foremost in the minds of decision-makers. This can explain why a great numbers of companies have neither a clear language policy nor formal language planning.

Clearly, specific settings have a strong impact on language management styles. Notably in the Swiss context, not only "languages are very important"(Head of Diversity at $<$ TCom A>), but the question of how to manage this diversity is politically and economically raised. While language courses might have become less important for some firms $-<$ Bank A $>$ closed down the formerly huge language department completely - others pay employees for language courses (e.g., $<$ TCom A $>,<$ Tab A $>$, $<$ Public Services A and B $>$ ). $<$ Ins $A>$ organizes cultural integration courses for those assigned to another country. Translation services are a norm for big companies, such as $<$ Pharma $\mathrm{A}$ and $\mathrm{B}>$ or $<$ Agro $\mathrm{A}>$ and $<$ Food A $>$, whatever the price is: "Of course it costs us to do that, but it does give the sense of inclusion", affirms the Head of D\&I in $<$ Pharma B $>$.

In comparison to the implementation of a diversity management strategy which confirms the proactive approach identified in this study (Yanaprasart, 2015 [107]), it is most of the time a reactive approach that is promoted to accommodate the multilingual reality. Having said all that, even if language is person-bound, the language issue should not be left at the individual level, and management actions can influence individual behaviors. On the organizational language management policy and measure, as we have seen, translation services are used by some companies to facilitate mutual understanding, whereas others argue that it's very important to start "a project to investigate risks which might come up when we don't do the translations of the documents" $<$ Bank $\mathrm{A}>$. In terms of the communication strategies in linguistically mixed teams, as the findings have demonstrated, initiatives came mostly from the awareness and sensibility of the plurilingual group leaders. If monolingual speech in a monolingual model (One Language $O N$ ly) is not effective anymore, "the possibility to express in the language that each member feels the most comfortable in" is an alternative ${ }^{18}$, this by means of changing language choices (One Language $A$ t a Time) or opting for the practices of code-switching or various forms of code-mixing in a plurilingual mode (One Language At All Time). Even a non-Swiss D\&I project manager at $<$ Bank $\mathrm{A}>$ is not reluctant to benefit from these forms of "plurilanguaging" ("over the years of course I become a little bit swissified").

In reality, language is an individual skill. Actually,

18 In the argument of the project manager of $<$ Pharma $\mathrm{A}>$, a part of Diversity \& Inclusion is to "recognize diversity in people", "meaning that some people are more comfortable to be able to speak their mother tongue". What the company tries to do is to let "people speak any language they want, whatever language they feel comfortable in is important". 
language diversity management is really not all about managing language(s), but also about managing people who carry this powerful resource. In this sense, both corporate language policy and strategy should, strategically, be championed by a top management that is linguistically aware, for instance, of the inability of some people to perform in the corporate language, which may generate resentment, frustration and withdrawal. Without the sufficient awareness of managers, the important professional input of very competent individuals is in danger of being lost ${ }^{19}$.

In terms of managerial focus, language has to be brought to the forefront. Actions by top management and its commitment may enhance or undermine the language policy-strategy. An executive board member of $<$ Public Service $B>$ recognizes that language has value for top management and that language capital should be considered as a business strategic asset. That being so, top management has to explain how and why language matters in dealing with the multilingual reality of global business, where and how language finds its place and purpose in an organization, in what way should language resources be managed to improve the overall performance of the firm. At this point, a major managerial challenge lies in preparing individuals to use their skills as the organization intends. People decide what and how particular language is used. Most challengingly of all, to identify conditions under which linguistic diversity in organizations constitutes not only "an added value", but particularly a strategic asset for the performance of the company, as illustrated in the reflection of $<$ Agro $A>$ :

We have established a way of positioning multilingualism in the context of our people strategy, to give it a truly strategic tonality, rather than an optional, tactical, obvious expedient thing to do to facilitate communication. [...] And that naturally makes us look upon multilingualism in a wholly different way. There is a conviction that there is much to be gained in this area, but we're denying ourselves a lot of value by not fully appreciating and recognizing the power of multilingualism in mixed groups ( $<$ Agro $\mathrm{A}>$ ).

Managing diversity requires changing the people, claim Loden/Rosener[108]. It's about changing "the mindset that people have", comments the Head of Diversity at $<$ Ins B $>$. In order for a diversity strategy to make a difference, it needs to be substantial, comprehensive and persuasive. The starting point is why change is needed, as suggested by the Head of D\&I from $<$ Bank $A>$ : "Because we are sitting in our comfort zone; you know we are successful, why should I change?"

Importantly, according to the person in charge of diversity

19 We know from research that if somebody talks to you with an accent and somebody does not talk to you with an accent, you will pay more attention to the one without the accent; even if they are giving equal value statements. And that becomes really important then to manage these differences that that person is given enough time to think, that person is given enough time to express themselves and you really listen to what they are saying beyond the accent or the bad words (laughs). So it's really not an easy solution (Head of D\&I, $<$ Pharma B $>$ ). at $<$ Ins $\mathrm{B}>$ ), to make change happen, it has to come from the heart and not just be understood: "if you want people to change their mindset and their behavior, you cannot connect with them only in the head, it's also in the heart and the emotion". As $<$ TCom A $>$ points out, "Language is a big key, if we want to speak to the heart of the people, and language should be managed differently".

As it comes out in the interviews, multilingual Switzerland and multilingualism in Switzerland are considered by the Heads of Diversity as an asset, despite the high cost of their management. The reason is not only because language resources can be capitalized and invested as a distinctive input to the firm's capabilities (e.g. "multilanguage capability"),(Yanaprasart [109]), but also because the locality of this small country in the heart of Europe provides an ideal environment for enhancing a good-great-right mix and inclusiveness in all aspects(Yanaprasart [110]).As explained by the Head of Diversity at $<$ Public Service A $>$, 'having a right mix' is conceptualized as a managerial strategic goal: "Each department has its goals, about the mixing of languages. It's going to be more important to have more a good mix, representative mix in management of different languages". For their opponents, however, languages mixed solutions are probably realistic only in a country like Switzerland, where the capacity to speak several languages is the norm and where cross-linguistic interactions are not an exception.

\section{Conclusions}

In this increasingly globalized business context whose reality is multilingual, language issues bring additional challenges in terms of organizational diversity management. Already by its nature, language management is complicated. In terms of "uniformity and standardization" or "diversity and localization", firms face the issue of determining what processes and procedures can be globally implemented and what practices should be locally responsive. A challenge is to accommodate as much as possible the diverse requirements of different contexts, goals, needs and requirements, and indeed to implement the appropriate language that is the most fitting for each of them. There is no one answer for all situations. A fine balancing act is required to accommodate global contacts without hindering local communication, with the principle of pragmatic language functionality.

Actually, in order to respond to the double demand of internationalization while valorizing the plurality of perspectives and the diversity of talents, it is becoming urgent to find some balance between a concept which is based on the transparency of language(s), one language fits all, considered as simple vehicles in the service of information transmission ("the language of communication is just the vehicle", Head of D\&I, $<$ Pharma B $>$ ) and a reflexive attitude, which is developed on the basis of the conceptual differences ("the vehicle I use to communicate my thoughts", idem.). The most difficult task is to determine 
the way that "the vehicle" can assume, at its best, its vehicular function (to optimize communication) as well as its constitutive role (to maximize conceptual tools).

Finally, implementing a multilingual model in action in a "multilingual inclusiveness culture" (cf. Yanaprasart, [111], [112]) can be the one that better values plurilingual speakers, recognizes their achievements, strengthens their uniqueness for collective goals by providing them diverse, creative, hybrid forms of linguistic tools to identify and explore 'innovative opportunities' (Holménet al. [113]), and finally to build a competitive advantage for companies, teams, and individuals.

\section{REFERENCES}

[1] Minx, E. 2008. Speaking of Diversity. In Synergy by Diversity. Real Life Examples of Cultural Diversity in Corporations, ed. byP. Köppel / Dominik Sandner, Bertelsmann Stiftung, 68-71.

[2] Akinci, Ergün, and Patrick Pohl. 2008. "Diversity at Deutsch Bank: BANKAMIZ. Provides Services for Turkish Customers in Germany."In Synergy by diversity. Real Life Examples of Cultural Diversity in Corporations, ed. by Petra Köppel, and Dominik Sander, 26-29. Gütersloh: Bertelsmann Stiftung.

[3] Appadurai, Arjun. 1996. Modernity At Large: Cultural Dimensions of Globalization. Minneapolis: University of Minnesota Press.

[4] Saulière, Jérôme. 2013. Organizational language boundaries and the dynamics of language change: three case studies in a French MNC, Proceedings of 29th EGOS Colloquium, Montréal, Canada: July 4-6, 2013. (http://www.academia.edu/3138345/Organizational_languag e boundaries and the dynamics of language change Thre e_case_studies_in_a_French_MNC)

[5] Berthoud, Anne-Claude, and Marcel Burger (eds). 2014. Repenser le rôle des pratiques langagières dans la constitution des espaces sociaux contemporains. Louvain-la-Neuve: De Boeck, Duculot.

[6] Zhu, Hua. 2014. "Piecing together the 'workplace multilingualism' jigsaw puzzle." Multilingua, 33 (1-2): 233-242.

[7] Louhiala-Salminen, Leena. 2013. "We use our Corporate Language in all Strategy Work - Unpacking the Notion of Corporate Language, Keynote address." Global Advances in Business Communication, 5th annual Tricontinental Conference, 29-31 May 2013, University of Antwerp.

[8] Welch, Denise E., and Laurence S. Welch. 2008. "The importance of language in international knowledge transfer." Management International Review 48 (3), 339-60.

[9] Angouri, Jo. 2014. "Multilingualism in the workplace. Language practices in multilingual contexts." Multilingua, 33 (1-2): 1-9.

[10] Vaara, Eero, Janne Tienari, Rebecca Marschan-Piekkari, and Risto Säntti. 2005. "Language and the circuits of power in a merging multinational corporation." Journal of Management Studies 42 (3): 595-623.

[11] Feely, Aland J., and Anne-Wil Harzing. 2003. "Language management in multinational companies." Cross-cultural Management: An International Journal 10 (2): 37-52.

[12] Lüdi, Georges, Katharina Höchle, Fee Steinbach, and Patchareerat Yanaprasart. 2012. "Stratégies d'inclusion et formes d'exclusion dans des interactions exolingues au travail." In Interactions cosmopolites. L'organisation de la participation plurilingue, ed. by Lorenza Mondada and Luci Nussbaum, 29-62. Limoges: Lambert Lucas.

[13] Steyaert, Chris, Anja Ostendorp, and Claudine Gaibrois. 2011. "Multilingual organizations as 'linguascapes': Negotiating the position of English through discursive practices." Journal of World Business, 46 (3): 270-278.

[14] Janssens, Maddy, and Chris Steyaert. 2013. "Re-considering language from a cosmopolitan understanding: Towards a multilingual franca approach in MNCs." Proceedings of 29th EGOS Colloquium, Montréal, Canada: July 4-6, 2013.

[15] Lüdi, Georges, Katharina Höchle, and Patchareerat Yanaprasart. 2010. "Plurilingual practices at multilingual workplaces." In Multilingualism at Work: From Policies to Practices in Public, Medical and Business Settings, ed. by Bernd Meyer, and Birgit Apfelbaum, 211-234. Amsterdam: John Benjamins.

[16] Chen, Stephen, Ronald Geluykens, and Chong-Ju Choi. 2006."The importance of language in global teams: a linguistic perspective." Management International Review 46 (6): $679-695$.

[17] Welch, Denise E., and Laurence S. Welch. 2008. "The importance of language in international knowledge transfer." Management International Review 48 (3), 339-60.

[18] Marsh, David, and Richard Hill. 2009. Etude sur la contribution du multilinguisme à la créativité. Rapport final. Bruxelles: Euro publics ca/cva. ww.europublic.com.

[19] Grin, François, and C. Sfreddo. 2010. "Besoins languistiques et stratégie de recrutement des entreprises" In Langues, Economie, Gestion, ed. by Behr et C. Lang. Paris: Editions Sorbonne Nouvelle.

[20] Berthoud, Anne-Claude, François Grin, and Georges Lüdi (eds). 2013. Exploring the Dynamics of Multilingualism. The DYLAN project. Amsterdam: John Benjamins.

[21] Marschan, Rebecca, Lawrence S. Welch, and Denice E. Welch. 1997. "Language: The forgotten factor in multinational management." European Management Journal 15 (5): 591-598.

[22] Adler, Nancy, and Allison Gunderson. 52008. International Dimensions of Organizational Behavior. Mason, Ohio: Thomson-South-Western.

[23] Manchen Spoerri, Sylvia, and Christiane Hohenstein. 2012. Linguistic Diversity in Cooperative Work Processes of Task-Oriented Teams. Wintherthur: ZHAW (Working Papers in Applied Linguistics 3).

[24] Piekkari, Rebecca, Denise E. Welch, and Lawrence S. Welch. 2015. Language in international business. The Multilingual Reality of Global Business Expansion. Cheltenham and Northampton: Edward Elgar. 
[25] Piekkari, Rebecca, Denise E. Welch, and Lawrence S. Welch. 2015. Language in international business. The Multilingual Reality of Global Business Expansion. Cheltenham and Northampton: Edward Elgar.

[26] Piekkari, Rebecca, Denise E. Welch, and Lawrence S. Welch. 2015. Language in international business. The Multilingual Reality of Global Business Expansion. Cheltenham and Northampton: Edward Elgar.

[27] van den Bergh, Samuel, and Ralph Lehmann. 2004. "Managing Multicultural Teams." In Proceedings of 15th EN Co De Conference. HTW Chur. The Cutting Edge Training to Communicate, ed. by Harald Löhndorf, 10-22.

[28] Hagen, Stephen. 2005. Language and culture in British business. London: CILT.

[29] Kameyama, Shinichi, and Bernd Meyer (eds). 2007. Mehrsprachigkeit am Arbeitsplatz. Frankfurt a.M et al.: Peter Lang.

[30] Gaibrois, Claudine. 2015. Power at work: The discursive constructing of power relations in multilingual organizations. Bamberg: Difo-Druck GmbH.

[31] Harzing, Anne-Wil, Kathrin Köster, and Ulrike Magner. 2011. "Babel in business: The language barrier and its solutions in the HQ - subsidiary relationship." Journal of World Business 46 (3): 279-287.

[32] Blazejewski, Susanne. 2006. "Transferring value-infused organizational practices in multinational companies: A conflict perspective". In Global, national and local practices in multinational corporations ed. by $\mathrm{M}$. Geppert, and $\mathrm{M}$. Mayer, 63-104. Houndmills, UK: Palgrave Macmillan.

[33] Fredriksson, Riikka, Wilhelm Barner-Rasmussen, and Rebecca Piekkari. 2006. "The multinational corporation as a multilingual organization: The notion of a common corporate language." Corporate Communications: An International Journal 11 (4): 406-423.

[34] Harzing, Anne-Wil, and Alan J. Feely. 2008. "The language barrier and its implications for HQ-subsidiary relationships." Cross Cultural Management: An International Journal 15 (1): 49-61.

[35] Maclean, Dirk. 2006. "Beyond English. Transnational corporations and the strategic management of language in a complex multilingual business environment." Management Decision 44 (10): 1377-1390.

[36] Planken, Brigitte. 2012. "The changing landscape of business communication: Developments and directions in research." In The language factor in international business: New perspectives on research, teaching and practice, ed. by P.Heynderickx, S. Dieltjens, G. Jacobs, P. Giééaerts and E. de Groot, 17-40. Bern: Peter Lang.

[37] Janssens, Maddy, José Lambert, and Chris Steyaert. 2004. "Developing Language Strategies for International Companies: The contribution of translation studies.” Journal of World Business, 39(4): 414-430.

[38] Lecomte, Philippe. 2012. "Introduction" In La question du langage et de la communication dans le management international: un défi pour les hommes et les organisations. Actes du 6ème Séminaire d'études du groupe GEM ESSEC BUSINESS SCHOOL, 28-30 mars 2012: 8-9 (http://geml.eu/wp-content/uploads/2014/06/Actes-du-colloq
ue-GEM-2012-final-21.pdf, accessed November, 12 2015)

[39] Berthoud, Anne-Claude, François Grin, and Georges Lüdi (eds). 2013. Exploring the Dynamics of Multilingualism. The DYLAN project. Amsterdam: John Benjamins.

[40] Marschan, Rebecca, Lawrence S. Welch, and Denice E. Welch. 1997. "Language: The forgotten factor in multinational management." European Management Journal 15 (5): 591-598.

[41] Reeves, Nigel, and Colin Wright. 1996. Linguistic Auditing. Clevedon: Multilingual Matters.

[42] Verrept, Simon. 2000. Keynote Speech. Paper presented at the European Association of Business Communication, Antwerp. Cited in Alan. J. Feely and Anne-Wil Harzing. 2002. Forgotten and Neglected Language: The Orphan of International Business Research, http://www.harzing.com/download/orphan.pdf

[43] Feely, Aland J., and Anne-Wil Harzing. 2002. Forgotten and neglected. Language the orphan of international business research. Birmingham: Aston Business School.

[44] Studer, Patrick, and Christian Hohenstein. 2011. Linguistic diversity in business contexts: a functional linguistic perspective. Wintherthur:ZHAW (Working Papers in Applied Linguistics 1).

[45] Manchen Spoerri, Sylvia, and Christiane Hohenstein. 2012. Linguistic Diversity in Cooperative Work Processes of Task-Oriented Teams. Wintherthur: ZHAW (Working Papers in Applied Linguistics 3).

[46] Planken, Brigitte. 2012. "The changing landscape of business communication: Developments and directions in research." In The language factor in international business: New perspectives on research, teaching and practice, ed. by P.Heynderickx, S. Dieltjens, G. Jacobs, P. Giééaerts and E. de Groot, 17-40. Bern: Peter Lang.

[47] Feely, Aland J., and Anne-Wil Harzing. 2003. "Language management in multinational companies." Cross-cultural Management: An International Journal 10 (2): 37-52.

[48] Kogut, Bruce, and Udo Zander. 1992. "Knowledge of the Firm, Combinative Capabilities, and the Replication of Technology." Organization Science 3 (3): 383-397.

[49] Luo, Yadong, and Oded Shenkar. 2006. The multinational corporation as a multilingual community: Language and organisation in a global context, Journal of International Business Studies, 37(3), 321-339.

[50] Hoecklin, Lisa. 1995. Managing cultural differences: Strategies for competitive advantage. London: Economist Intelligence Unit/ Addison Wesley.

[51] Large, Andrew. 1985. The artificial language movement. London: Basil Blackwell/Andre Deutsch.

[52] Peters, Tom J., and Robert H. Waterman. 1982. In search of excellence: Lessons from America's best-run companies. New York: Harper \& Row.

[53] Steiner, George. 1975. After Babel: Aspects of language and translation. London: Oxford University Press.

[54] Hedlund, Gunnar. 1999. "The Multinational Corporation as a Nearly Recomposable System (NRS)." Management International Review 39 (Special Issue 1): 5-44. 
[55] Collins, David. 2000. Management Fads and buzzwords. London: Routledge.

[56] Senge, Peter. 1990. The Fifth Discipline: The Art and Practice of the Learning Organization. London: Century.

[57] Argote, Linda, Bill McEvily, and Ray Reagans. 2003. "Managing Knowledge in Organizations: An Integrative Framework and Review of Emerging Themes." Management Science 49 (4): 571-582.

[58] Phene, Anupama, AnoopMadhok, and Kun Liu. 2005. "Knowledge Transfer within the Multinational Firm." Management International Review 45, Special Issue 2, 53-74.

[59] Holden, Nigel J. 2002. Cross-cultural management. A Knowledge Management Perspective. London: Pearson Education.

[60] Hedlund, Gunnar. 1999. "The Multinational Corporation as a Nearly Recomposable System (NRS)." Management International Review 39 (Special Issue 1): 5-44.

[61] Peters, Tom J., and Robert H. Waterman. 1982. In search of excellence: Lessons from America's best-run companies. New York: Harper \& Row.

[62] Harzing, Anne-Wil, Kathrin Köster, and Ulrike Magner. 2011. "Babel in business: The language barrier and its solutions in the HQ - subsidiary relationship." Journal of World Business 46 (3): 279-287.

[63] Abdullah, Sayeh S., and Mohammad Latif Chaduhary. 2012. "English as a Global Lingua Franca, International Conference proceedings on Education."Applied Sciences and Management, December 26-27, Dubai, 128-133.

[64] Vandermeeren, Sonja. 1998. Fremdsprachen in europäischen Unternehmen. Untersuchungen zu Bestand und Bedarf im Geschäftsalltag mit Empfehlungen für Sprachenpolitik und Sprachunterricht. Waldsteinberg: Heidrun Popp.

[65] Barner-Rasmussen, Wilhelm, and Christoffer Aarnio. 2011. "Shifting the fault lines of language: A quantitative functional-level exploration of language use in MNC subsidiaries." Journal of World Business 46: 288-295.

[66] Heikkilä, Jukka Pekka, and Adam Smale. 2011. "The effects of 'language standardization' on the acceptance and use of e-HRM systems in foreign subsidiaries." Journal of World Business 46 (3): 305-313.

[67] Lüdi, Georges, Katharina Höchle, and Patchareerat Yanaprasart. 2013. "Multilingualism and Diversity Management in Companies in the Upper Rhine Region." In Exploring the Dynamics of Multilingualism. The DYLAN projected. by Anne-Claude Berthoud, François Grin, and Georges Lüdi, 59-82.Amsterdam: John Benjamins.

[68] Lüdi, Goerges, Katharina Höchle, and Patchareerat Yanaprasart. eds. forthcoming. Managing Plurilingual and Intercultural Practices in the Workplace. The Case of Multilingual Switzerland, Amsterdam: John Benjamins.

[69] Maclean, Dirk. 2006. "Beyond English. Transnational corporations and the strategic management of language in a complex multilingual business environment." Management Decision 44 (10): 1377-1390.

[70] Angouri, Jo, and Marlene Miglbauer. 2013. "Local languages and communication challenges in the multinational workplace." In Language and Intercultural Communication in the New Era, ed. by Farzad Sharifian, and Maryam Jamarani, 225-245. London: Routledge.

[71] Berthoud, Anne-Claude, François Grin, and Georges Lüdi (eds). 2013. Exploring the Dynamics of Multilingualism. The DYLAN project. Amsterdam: John Benjamins.

[72] Lüdi, Georges. 2013. "Englisch als lingua franca und/oder Mehrsprachigkeit? ”Babylonia 2/13: 10-16.

[73] Ehrenreich, Susanne. 2009. "English as a Lingua Franca in multinational corporations - exploring business communities of practice." In English as a Lingua Franca. Studies and Findings, ed. by Anna Mauranen, and Elina Ranta, 126-151. Newcastle upon Tyne: Cambridge Scholars Publishing.

[74] Pullin Stark, Patricia. 2010. "Small talk, rapport, and international communicative competence. Lessons to learn from BELF." Journal of Business Communication 47(4): $455-476$.

[75] Lüdi, Georges, Katharina Höchle, and Patchareerat Yanaprasart. 2013. "Multilingualism and Diversity Management in Companies in the Upper Rhine Region." In Exploring the Dynamics of Multilingualism. The DYLAN projected. by Anne-Claude Berthoud, François Grin, and Georges Lüdi, 59-82.Amsterdam: John Benjamins.

[76] Lüdi, Georges. 2014. "Language management measures and their impact in companies operating in a context of linguistic diversity." In: Multilingual Encounters in Europe's Institutional Spaces, ed. by Johann W. Unger, Michal Kryzanowski, and Ruth Wodak, 15-42. London: Bloomsbury.

[77] Cogo, Alessia. 2012. "ELF and super-diversity: a case study of ELF multilingual practices from a business context." Journal of English as a Lingua Franca 1(2): 287-313.

[78] Hülmbauer, Cornelia, and Barbara Seidlhofer. 2013. "English as a Lingua Franca in European Multilingualism." In Exploring the Dynamics of Multilingualism. The DYLAN projected. by Anne-Claude Berthoud, François Grin, and Georges Lüdi, 387-406.Amsterdam: John Benjamins.

[79] Charles, Mirjaliisa. 2007. "Language matters in global communication." Journal of Business Communication 44(3): 260-282.

[80] Chew, Kheng-Suan. 2005. "An investigation of the English language skills used by new entrants in banks in Hong Kong." English for Specific Purposes 24(4): 423-435.

[81] Erling, Elizabeth, and Alan Walton (2007). "English at work in Berlin."English Today 23 (1): 32-40.

[82] Evans, Stephen. 2013. "Designing tasks for the Business English classroom." English Language Teaching Journal 67 (3): 281-293

[83] Hua, Zhu, Hua. 2014. "Piecing together the "workplace multilingualism' jigsaw puzzle." Multilingua, 33 (1-2): 233-242.

[84] Cogo, Alessia, and Patchareerat Yanaprasart. forthcoming. "English is the language of business: An exploration of language ideologies in two European corporate contexts." In English in Business and Commerce: Interactions and Policies, 5th volume of the English in Europe sub-series, ed. by Jiri Nevkapil, and Tamah Sherman. Mouton de Gruyter's Language and Social Processes (LSP)'. 
[85] Schnurr, Stephanie. 2013. Exploring Professional Communication Language in Action. New York: Routledge.

[86] Dyer, Patricia M. 1983. Instructional Procedure for Implementing the Strategic Interaction Method in an Intensive English as a Second Language Program. Doctoral Dissertation, University of Delaware. Ann Arbor: UMI.

[87] Piekkari, Rebecca, Denise E. Welch, and Lawrence S. Welch. 2015. Language in international business. The Multilingual Reality of Global Business Expansion. Cheltenham and Northampton: Edward Elgar.

[88] Piekkari, Rebecca, Denise E. Welch, and Lawrence S. Welch. 2015. Language in international business. The Multilingual Reality of Global Business Expansion. Cheltenham and Northampton: Edward Elgar.

[89] Maclean, Dirk. 2006. "Beyond English. Transnational corporations and the strategic management of language in a complex multilingual business environment. "Management Decision 44 (10): 1377-1390.

[90] Yanaprasart, Patchareerat. 2015. "Multilinguaculturing: Making an asset of multilingual human resources in organizations." In Routledge Companion to Cross-Cultural Management, ed. by Nigel Holden, Snejina Michailova, and Susanne Tietze, 112-130, London and New York: Routledge.

[91] Piekkari, Rebecca, Denise E. Welch, and Lawrence S. Welch. 2015. Language in international business. The Multilingual Reality of Global Business Expansion. Cheltenham and Northampton: Edward Elgar.

[92] Abdullah, Sayeh S., and Mohammad Latif Chaduhary. 2012. "English as a Global Lingua Franca, International Conference proceedings on Education."Applied Sciences and Management, December 26-27, Dubai, 128-133.

[93] Müller-Jentsch, Daniel. 2009. „Auf der Jagd nach den Besten." Terra Cognita 14. Neue Migrationslandschaft, $54-57$.

[94] Seidlhofer, Barbara. 2005. "English as a lingua franca", ELT Journal 59 (4): 339-341.

[95] Hülmbauer, Cornelia, and Barbara Seidlhofer. 2013. "English as a Lingua Franca in European Multilingualism." In Exploring the Dynamics of Multilingualism. The DYLAN projected. by Anne-Claude Berthoud, François Grin, and Georges Lüdi, 387-406.Amsterdam: John Benjamins.

[96] Markaki, Vassiliki, Sara Merlino, Lorenza Mondada, Florence Oloff, and VéroniqueTraverso. 2013. "Multilingual practices in professional settings: keeping the delicate balance between progressivity and intersubjectivity." In Exploring the Dynamics of Multilingualism. The DYLAN projected. by Anne-Claude Berthoud, François Grin, and Georges Lüdi, 3-32.Amsterdam: John Benjamins.

[97] Lüdi, Georges, Katharina Höchle, and Patchareerat Yanaprasart. 2013. "Multilingualism and Diversity Management in Companies in the Upper Rhine Region." In Exploring the Dynamics of Multilingualism. The DYLAN projected. by Anne-Claude Berthoud, François Grin, and Georges Lüdi, 59-82.Amsterdam: John Benjamins.

[98] Harzing, Anne-Wil, and Markus Pudelko. 2013. "Language competencies, policies and practices in multinational corporations. A comprehensive review and comparison of Anglophone, Asian, Continental European and Nordic
MNCs." Journal of World Business 48, 279-287.

[99] Piekkari, Rebecca, Denise E. Welch, and Lawrence S. Welch. 2015. Language in international business. The Multilingual Reality of Global Business Expansion. Cheltenham and Northampton: Edward Elgar.

[100] Babcock, Richard D., and Bertha Du-Babcock. 2001. "Language-based communication zones in international business communication." Journal of Business Communication 38 (4): 372-412.

[101] Kolde, Gottfried. 1981. Sprachkontakte in gemischtsprachigen Städten. Vergleichende Unter-suchungen über Voraussetzungen und Formen sprachlicher Interaktion verschiedensprachiger Jugendlicher in den Schweizer Städten Biel/Bienne und Fribourg/Freiburg i. Ue. Zeitschrift für Dialektologie und Linguistik, Beihefte H. 37. Wiesbaden: Steiner.

[102] Werlen, Iwar. 2007. "Receptive multilingualism in Switzerland and the case of Biel/Bienne." In Receptive Multilingualism: Linguistic analyses, language policies and didactic concepts, ed. by Jan D. ten Thije, and Ludger Zeevaert, 137-157. Amsterdam: John Benjamins.

[103] Lüdi, Georges. 2007. "The Swiss model of plurilingual communication." In Receptive Multilingualism: Linguistic analyses, language policies and didactic concepts ed. by Jan D. ten Thije, and Ludger Zeevaert, 159-177. Amsterdam: John Benjamins.

[104] ten Thije, Jan D. and Ludger Zeevaert (eds). 2007. Receptive Multilingualism. Linguistic analyses, language policies and didactic concepts. Amsterdam: Benjamins.

[105] Lüdi, Georges, Katharina Höchle, and Patchareerat Yanaprasart. 2013. "Multilingualism and Diversity Management in Companies in the Upper Rhine Region." In Exploring the Dynamics of Multilingualism. The DYLAN projected. by Anne-Claude Berthoud, François Grin, and Georges Lüdi, 59-82.Amsterdam: John Benjamins.

[106] Lüdi, Georges. 2007. "Objectif : des compétences plurilingues mobilisables comme ressource pour gérer des situations de communication plurielles." In La compétence plurilingue : regards francophones, ed. by Danièle Moore and Véronique Castellotti, 207-219. Bern et al.:, Peter Lang.

[107] Yanaprasart, Patchareerat. 2015. Scientific Report. "Diversity management practices: measures and indicators", Swiss National Scientific Foundation, September 2015.

[108] Loden, Marilyn, and Judy B. Rosener. 1991. Workforce America! Managing Employee Diversity as a Vital Resource. United States: Irwin/McGraw-Hill Publishing.

[109] Yanaprasart, Patchareerat. 2015. "Multilinguaculturing: Making an asset of multilingual human resources in organizations." In Routledge Companion to Cross-Cultural Management, ed. by Nigel Holden, Snejina.

[110] Yanaprasart, Patchareerat. Forthcoming. Chapter 2: The Challenge of the Management of Diversity. In Managing Plurilingual and Intercultural Practices in the Workplace. The Case of Multilingual Switzerland, ed. by Lüdi, Goerges, Katharina Höchle, and Patchareerat Yanaprasart. Amsterdam: John Benjamins.

[111] Yanaprasart, Patchareerat. Forthcoming. Two logics in Tension: Principle of Economy versus. Principle of 
Inter-comprehension, Journal of Linguistic Anthropology.

[112] Yanaprasart, Patchareerat. Forthcoming. Cultural diversity: Interplay between corporate culture, organizational diversity management and multilingual inclusiveness. In Handbook Language in Organization, ed. by Stephan Habscheid, Andreas Müller, Britta Thörle, Antje Wilton (Handbboks "Sprachwissen" (HSW), Ekkehard Felder / Andreas Gardt (eds)), Berlin/Boston: De Gruyter.

[113] Holmén, Magnus, Mats Magnusson, and Maureen McKelvey. 2007. What are Innovative Opportunities? Industry and Innovation, Vol. 14, Issue 1, 2007, 27-45.

[114] [Footnote 2] De Groot, Elizabeth Bouchien. 2012. "Personal preference or policy? Language choice in a European-based international organization."Corporate Communications: An International Journal 17 (3): 255-71.
[115] [Footnote 3]Hagen, Stephen. 2011. Report on Language Management Strategies and Best Practice in European SMEs: the PIMLICO Project. http://ec.europa.eu/languages/policy/s trategic-framework/documents/pimlico-full-report_en.pdf (accessed January 7, 2016).

[116] Minzberg, Henry, and James A. Waters. 1985. "Of strategies, deliberate and emergent." Strategic Management Journal 6 (3): $257-272$.

[117] Piekkari, Rebecca, Denise E. Welch, and Lawrence S. Welch. 2015. Language in international business. The Multilingual Reality of Global Business Expansion. Cheltenham and Northampton: Edward Elgar.

[118] [Footnote 13] Canagarajah, A. Suresh. (2009). Multilingual strategies of negotiating English: From conversation to writing. Journal of Advanced Composition, 29, 711-743. 